\title{
Effects of administration of sertraline, clozapine, amitriptyline and imipramine on brain serotonin, liver enzymes and blood chemistry of rabbit
}

\author{
O. A. T. EBUEHI ${ }^{*}$, C. E. IKANONE, A. A. BALOGUN, A. I. AKINWANDE and \\ O.O. FAMUYIWA
}

Department of Biochemistry, College of Medicine, University of Lagos, P.M.B. 12003, Lagos, Nigeria.

* Corresponding author, Email: ebuehi@yahoo.com

\begin{abstract}
The chronic administration of sertraline, clozapine, amitriptyline and imipramine on brain serotonin, liver enzymes and blood chemistry of rabbits were investigated. Sixty rabbits were equally divided into 5 groups and each group was intraperitoneally administered $2 \mathrm{ml}$ of $0.5 \mathrm{mg}$ of the respective drug/kg body weight/day) and saline as control for 28 days. After 28 days, the rabbits were sacrificed; blood taken, liver and brain were excised. The concentration of total protein, serotonin, cholesterol and triglyceride in serum, liver and brain were determined. The activities of serum and liver alkaline phosphatase (ALP), aspartate transaminase (AST) and alanine transaminase were also assayed. The serum serotonin and brain serotonin levels in rabbits administered the respective drugs were significantly $(p<0.01)$ higher than in rabbits administered saline. Brain protein and cholesterol levels in rabbit administered saline were significantly lower than in those administered sertraline, clozapine, amitriptyline and imipramine, with no difference in the serum protein levels. The activities of serum and liver AST and ALT of rabbits administered saline were significantly lower than in those administered the respective drugs, with the exception of serum ALP. Data from the study indicate that intraperitoneal administration of imipramine or amitriptyline produced a more pronounced effect on brain serotonin, activities of liver derived enzymes in serum and blood chemistry of rabbits compared to sertraline or clozapine.

(C) 2009 International Formulae Group. All rights reserved.
\end{abstract}

Keywords: Antidepressant drugs, serotonin, enzymes, blood chemistry.

\section{INTRODUCTION}

Major depression is one of the most common psychiatric disorders afflicting mankind. It is believed to arise from disturbances in brain neurotransmitters' systems. For the past 30 years, monoamine hypothesis of depression has been the theory of explaining biological basis of depression (Trujillo et al., 1996), which states that depression is essentially due to a deficiency in one of the three neurotransmitters, serotonin, norepinephrine and dopamine (Feldman et al., 1997; Feighner, 1999). A considerable number of drugs and drug combinations have been associated with the serotonin syndrome, e.g. monoamine oxidase inhibitors, tricyclic antidepressants, etc. (Parrot, 2002).
Sertraline and clozapine belong to antidepressant and antipsychotic drugs respectively, while imipramine and amitriptyline are tricyclic antidepressants. Biochemical studies on imipramine demonstrated that this drug increased the activity of monoamine neurotransmitters, norepinephrine and serotonin by inhibiting their reuptake into neurons (Barker et al., 1992; Camarini and Benedito, 1997; Cantrell et al., 1999). Sertraline is an oral antidepressant drug of the selective serotonin reuptake type. It increases serotonin level in the CNS by inhibiting reuptake of serotonin (Cohen et al., 1989; Bustillo et al., 1996; Solai et al., 1997; Cottinghan, 2000). 
Serotonin is a neurotransmitter, synthesized from tryptophan and is responsible for emotional stability, mood, anxiety, arousal, aggression, nutrient selection, sleep and sex (Fernstrom and Hirsch, 1977). Antipsychotic drugs can ameliorate the types of delusions and hallucinations characteristic of bipolar disorder (such as depression and schizophrenia) (McConcghy et al., 1968; Klerman and Cole, 1976; Liberman et al., 1994). They act in part by blocking dopamine receptors at the synapse reducing brain activity. Its therapeutic effects are probably mediated by dopaminergic and serotoninergic activities (Kane et al., 1989, GoodmanGilman et al., 2006).

There is paucity of information on the effect of these antidepressants on neurotransmitters, liver enzymes and blood chemistry. With the increasing usage of these antidepressants and drugs in the management of psychiatric disorders, it is therefore required to understand as to whether these drugs affect brain serotonin levels, activities of liver enzymes and blood chemistry of patients. The aim of the present study therefore, is to determine whether chronic administration of sertraline, clozapine, amitriptyline and imipramine affect brain serotonin level, activities of liver enzymes and blood chemistry of rabbits.

\section{MATERIALS AND METHODS Drugs}

Tablets of sertraline (50 mg) were manufactured by Pfizer Italian S. P. A., Latina, Italy under authority of Pfizer Inc., New York, USA. Tablets of amitriptyline (25 mg) were manufactured by Anphar laboratories Ltd, Jammu and Kahmir, India and while that of imipramine and clozapine were manufactured by Novartis Pharmaceuticals.

Five tablets of $100 \mathrm{mg}$ of clozapine were homogenized and dissolved in 1 litre of saline concentration; $2 \mathrm{ml}$ of $0.5 \mathrm{mg} / \mathrm{ml}$ clozapine solution were intraperitoneally administered per $\mathrm{kg}$ body weight of rabbits. 10 tablets of $50 \mathrm{mg}$ sertraline were homogenized and dissolved in 1 litre of saline to produce $0.5 \mathrm{mg} / \mathrm{ml}$ drug solution. 20 tablets of $25 \mathrm{mg}$ amitriptyline or imipramine were homogenized and dissolved in 1 litre of saline to produce $0.5 \mathrm{mg} / \mathrm{ml}$ drug solution.

\section{Drug administration}

Sixty rabbits $(1.06 \pm 0.031 \mathrm{~kg} ; 3.2 \pm 0.05$ months) were equally divided into 5 groups, and kept in a room with a temperature of $28 \pm 2$ ${ }^{\circ} \mathrm{C}$, illuminated for $12 \mathrm{~h}$ per day (07:00-19:00 h). Three rabbits were housed in each metallic cage and fed with commercial rabbit pellet containing $21 \%$ protein and water ad libitum for 14 days in order to acclimatize them.

After 14 days of acclimatization, the rabbits were intraperitoneally (i.p) administered $2 \mathrm{ml}$ of $0.5 \mathrm{mg}$ per $\mathrm{kg}$ body weight of sertraline, clozapine, amitryptyline, imipramine and $0.89 \%$ saline daily for 28 days between 08:00 and 10:00 h. Each group labeled A, B, C, D and E comprising 12 rabbits were separately administrated the respective drugs or saline. Groups A, B, C and $\mathrm{D}$, represent rabbits administered sertraline, clozapine, amitryptyline and imipramine respectively, while Group E administered saline served as control. The body weight, feed and water intake of the rabbits were computed every other day. From these values, the organo-somatic index (OSI) was calculated using the following formula:

Organo-somatic index: Weight (g) of the organ/Day 28 total body weight (g) x 100 .

Three rabbits from each group were sacrificed by decapitation after an overnight fast weekly. Blood was quickly taken by cardiac puncture into a heparinized tube. The brain and liver were excised. The organs were dried and weighed, placed on ice before storage at -20 ${ }^{\circ} \mathrm{C}$ until further analysis. Blood was centrifuged at $3000 \mathrm{xg}$ for $10 \mathrm{~min}$ in an automated refrigerated centrifuge and the plasma was extracted. One gram of brain or liver was homogenized with $10 \mathrm{ml}$ of ice cold $0.05 \mathrm{M}$ phosphate buffer, $\mathrm{pH}$ 7.0, using a Teflon glass homogenizer. The homogenate was centrifuged at $2500 \mathrm{xg}$ for $15 \mathrm{~min}$ and the supernatant obtained was stored for further analysis. The serotonin concentrations in the brain and liver supernatants were determined using high performance liquid chromatography (HPLC), Agilent 100 series with VWD detector degasser, Quat Pump, Col Com and a manual injector system.

Tissue samples were prepared for injection by liquid phase extraction using 
chilled acetonitrile for deproteinization. The mixture was spiked with an internal standard, 3,4-dihydroxybenzylamine (DHBA) and using a vortex mixer for $1 \mathrm{~min}$. The mixture was centrifuged at $10,000 \mathrm{xg}$ for $10 \mathrm{~min}$; the supernatant was collected and injected into the column. A gradient HPLC method was used for analysis of liver and brain serotonin. Chromatographic separations were carried out on a Hypersil ODS C18 reverse phase column (250 x $4.0 \mathrm{~mm}$ ) packed with $5 \mathrm{~mm}$ particles. The column was maintained at $25^{\circ} \mathrm{C}$. The mobile phase was $0.025 \mathrm{M}$ phosphate buffer containing $200 \mathrm{mg}$ 1-octanesulfonate in distilled water ( $\mathrm{pH} 4.3)$ and C-methanol. The mobile phase was pumped at $70 \%$ of the buffer and 30\% of methanol. The flow rate was $1.0 \mathrm{ml} / \mathrm{min}$ and wavelength detector was $280 \mathrm{~nm}$. The stock solutions of serotonin (5HT) and internal standard, DHBA were prepared in distilled water at a concentration of $50 \mathrm{~g} / \mathrm{ml}$. The working standard solutions of 5-HT in 5-HT - free protein solutions in situ.

For each run, serotonin and DHBA standards were processed to identify retention times and to confirm the serotonin elution peak from samples. In all cases, $50 \mathrm{ml}$ of samples and standards were injected into the column. The signal from the VWD detector was fed directly to the agilent data acquisition system. The serotonin content was determined by comparing serotonin/DHBA peak height ratios of unknown sample chromatograms with those of chromatograms of serotonin standard used as calibrator.

Protein concentration was assayed by the method of Lowry et al. (1951). The levels of cholesterol and triglyceride in the serum, liver and brain were determined using Synchron CX5 autoanalyzer. The activities of serum aspartate transaminase (AST, EC 2.6.1.1), alanine transaminase (ALT, EC 2.6.1.2), and alkaline phosphatase (EC 3.1.3.1) were assayed at $37^{\circ} \mathrm{C}$ according to the recommended principles (Steffensen et al., 1977). Commercial kits manufactured by Boehringer, Mannheim, Germany and Roche, Switzerland were used.

\section{Statistical analysis}

Data of the study were analyzed by one-way analysis of variance (ANOVA) using Graph Pad Instat, Benferoni. A value of $\mathrm{p}<0.01$ was considered highly significant.
Data were expressed as mean \pm standard deviation.

\section{Ethics}

This work was carried out in accordance with the ethical guidelines for animal care and use (Zimmerman, 1983).

\section{RESULTS}

Results of the changes in body weight, feed and water intake of rabbits administered (i.p) sertraline, clozapine, amitriptyline, imipramine and saline for 28 days are shown in Table 1. There was a significant $(\mathrm{p}<0.01)$ increase in body weights of rabbits administered the respective drugs or saline after 28 days. However, the body weights of rabbits administered amitriptyline and imipramine were significantly higher than in rabbits administered sertraline, clozapine or saline. Mean feed and water intake of rabbits administered amitriptyline and imipramine were significantly $(\mathrm{p}<0.01)$ higher than in sertraline, clozapine or saline administered rabbit (Table 1). However, the mean feed or water intake of rabbits administered saline was significantly $(p<0.01)$ lower than in rabbits administered sertraline, clozapine, amitriptyline and imipramine.

The results of mean liver and brain weights, organo-somatic index of livers or brains of rabbits administered the respective drugs and saline are presented in Table 2. The mean liver weight of rabbits administered imipramine was significantly $(\mathrm{p}<0.01)$ higher than in rabbits administered sertraline or clozapine or amitriptyline or saline. There was no significant difference in organo-somatic index of livers of rabbits administered the respective drugs or saline (Table 2).The mean brain weight of rabbits administered saline was significantly $(p<0.01)$ higher than in rabbits administered sertraline, clozapine, amitriptyline, imipramine and saline. However, mean brain weights of rabbits administered clozapine were significantly the lowest as compared to rabbits administered other drugs (Table 2). The organo-somatic index of brain of rabbits administered saline was significantly $(\mathrm{p}<0.01)$ lower than in rabbits administered sertraline or clozapine, but higher in rabbits administered amitriptyline or imipramine (Table 2). 
Table 1: Changes in body weight, feed and water intake of rabbits administered (i.p) sertraline, clozapine, amitriptyline, imipramine and saline after 28 days.

\begin{tabular}{lccc}
\hline $\begin{array}{l}\text { Drug } \\
\text { Administration }\end{array}$ & $\begin{array}{c}\text { Mean body weight } \\
(\mathbf{k g} / \text { rabbit) }\end{array}$ & $\begin{array}{c}\text { Mean feed intake } \\
\text { (g/rabbit/day) }\end{array}$ & $\begin{array}{c}\text { Mean water intake } \\
(\mathbf{m l} / \text { rabbit / day) }\end{array}$ \\
\hline Sertraline & $1.16 \pm 0.04^{\mathrm{a}}$ & $30.86 \pm 2.14^{\mathrm{a}}$ & $71.09 \pm 3.06^{\mathrm{a}}$ \\
Clozapine & $1.36 \pm 0.05^{\mathrm{b}}$ & $34.22 \pm 3.45^{\mathrm{a}}$ & $72.60 \pm 4.82^{\mathrm{a}}$ \\
Amitriptyline & $1.60 \pm 0.07^{\mathrm{c}}$ & $59.29 \pm 1.62^{\mathrm{b}}$ & $95.39 \pm 6.79^{\mathrm{b}}$ \\
Imipramine & $1.58 \pm 0.02^{\mathrm{c}}$ & $52.67 \pm 4.73^{\mathrm{b}}$ & $93.71 \pm 3.05^{\mathrm{b}}$ \\
Saline & $1.30 \pm 0.03^{\mathrm{b}}$ & $31.51 \pm 1.18^{\mathrm{a}}$ & $75.16 \pm 3.64^{\mathrm{a}}$ \\
\hline Values are expressed as Mean \pm SD; $(\mathrm{n}=10)$. &
\end{tabular}

Table 2: Liver and brain weights of rabbits administered (i.p) sertraline, clozapine, amitriptyline, imipramine and saline after 28 days.

\begin{tabular}{|c|c|c|c|c|}
\hline $\begin{array}{l}\text { Drug } \\
\text { administration }\end{array}$ & $\begin{array}{c}\text { Mean liver weight } \\
\text { [g/rabbit] }\end{array}$ & $\begin{array}{c}\text { Organo-somatic } \\
\text { index* [ liver }(\%)]\end{array}$ & $\begin{array}{c}\text { Mean brain weight } \\
\text { [g/rabbit] }\end{array}$ & $\begin{array}{c}\text { Organo-somatic } \\
\text { index [brain (\%)] }\end{array}$ \\
\hline Sertraline & $27.64 \pm 2.18^{\mathrm{a}}$ & $2.08 \pm 0.16^{\mathrm{a}}$ & $6.07 \pm 0.18^{\mathrm{a}}$ & $0.55 \pm 0.08^{\mathrm{a}}$ \\
\hline Clozapine & $28.77 \pm 1.43^{\mathrm{a}}$ & $2.10 \pm 0.34^{\mathrm{a}}$ & $4.81 \pm 0.32^{\natural}$ & $0.53 \pm 0.14^{\mathrm{a}}$ \\
\hline Amitriptyline & $26.21 \pm 1.05^{\mathrm{a}}$ & $1.86 \pm 0.28^{\mathrm{b}}$ & $5.46 \pm 0.47^{\mathrm{c}}$ & $0.31 \pm 0.07^{\mathrm{b}}$ \\
\hline Imipramine & $33.22 \pm 0.46^{\mathrm{b}}$ & $1.92 \pm 0.17^{\mathrm{b}}$ & $6.14 \pm 0.59 a$ & $0.34 \pm 0.05^{\mathrm{b}}$ \\
\hline Saline & $26.78 \pm 1.13^{\mathrm{a}}$ & $1.81 \pm 0.15^{b}$ & $6.46 \pm 0.21 \mathrm{a}$ & $0.44 \pm 0.06^{\mathrm{c}}$ \\
\hline
\end{tabular}

The concentrations of serotonin in sera and brains of rabbits administered (i.p) sertraline, clozapine, amitriptyline, imipramine and saline are shown in Table 3. The serum serotonin and brain serotonin levels in rabbits administered the respective drugs were significantly $(p<0.01)$ higher than in rabbits administered saline. However, rabbits administered imipramine had the highest serum serotonin levels, while brain serotonin levels were highest in sertraline administered rabbits (Table 3).

The brain concentrations of total protein, cholesterol and triglyceride of rabbits administered (i.p) sertraline, clozapine, amitriptyline, imipramine and saline are presented in Table 4. Brain protein and cholesterol levels in rabbits administered saline were significantly $(\mathrm{p}<0.01)$ lower than in rabbits administered sertraline, clozapine, amitriptyline and imipramine (Table 4). There was no significant $(\mathrm{p}<0.01)$ difference in the brain cholesterol levels of rabbits administered the respective drugs. Significant $(\mathrm{p}<0.01)$ differences do not exist in brain protein levels of rabbits administered sertraline, amitriptyline and imipramine. The brain protein level of rabbits administered clozapine was significantly $(\mathrm{p}<0.01)$ reduced.

The liver concentrations of total protein, cholesterol and triglyceride of rabbits administered sertraline, clozapine, amitriptyline, imipramine and saline are presented in Table 5. Liver protein level of rabbits administered saline was significantly $(\mathrm{p}<0.01)$ lower than in rabbits administered sertraline, clozapine, amitriptyline or imipramine. There was no significant difference in liver protein level of rabbits administered sertraline or clozapine, amitriptyline or imipramine. The liver cholesterol levels of rabbits administered saline was significantly $(\mathrm{p}<0.01)$ lower than in rabbits administered sertraline or clozapine, while it was higher in amitriptyline or imipramine administered rabbits (Table 5). Liver triglyceride level of rabbits administered saline was significantly lower than in rabbits administered the respective drugs (Table 5). 
Table 3: Concentration of serotonin in serum and brain of rabbits administered (i.p) sertraline, clozapine, amitriptyline, imipramine and saline after 28 days.

\begin{tabular}{lcc}
\hline Drug administration & Serum serotonin $(\mu \mathrm{g} / \mathbf{m l})$ & Brain serotonin $(\mu \mathrm{g} / \mathbf{m l})$ \\
\hline Sertraline & $5.86 \pm 0.43^{\mathrm{a}}$ & $7.86 \pm 0.46^{\mathrm{a}}$ \\
Clozapine & $5.05 \pm 0.38^{\mathrm{b}}$ & $7.05 \pm 0.54^{\mathrm{b}}$ \\
Amitriptyline & $5.49 \pm 0.52^{\mathrm{a}}$ & $6.84 \pm 0.70^{\mathrm{b}}$ \\
Imipramine & $6.23 \pm 0.27^{\mathrm{b}}$ & $6.37 \pm 0.43^{\mathrm{c}}$ \\
Saline & $4.20 \pm 0.65^{\mathrm{c}}$ & $5.51 \pm 0.38^{\mathrm{d}}$ \\
\hline
\end{tabular}

Values are expressed as Mean \pm SD; $\quad(n=10)$

Values carrying different superscripts vertically are significantly $(\mathrm{p}<0.01)$ different.

Table 4: Concentrations of total protein, cholesterol and triglyceride in the brain of rabbits administered (i.p) sertraline, clozapine, amitriptyline, imipramine and saline after 28 days.

\begin{tabular}{lccc}
\hline $\begin{array}{l}\text { Drug } \\
\text { administration }\end{array}$ & \multicolumn{3}{c}{ Brain } \\
\cline { 2 - 4 } & Protein (g/l) & Cholesterol (mmol/l) & Triglyceride (mmol/l) \\
\hline Sertraline & $41.14 \pm 2.06^{\mathrm{a}}$ & $1.60 \pm 0.24^{\mathrm{a}}$ & $8.45 \pm 0.65^{\mathrm{a}}$ \\
Clozapine & $29.65 \pm 1.14^{\mathrm{b}}$ & $1.50 \pm 1.76^{\mathrm{b}}$ & $9.03 \pm 0.92^{\mathrm{b}}$ \\
Amitriptyline & $38.91 \pm 2.49^{\mathrm{a}}$ & $1.69 \pm 0.07^{\mathrm{c}}$ & $9.75 \pm 0.73^{\mathrm{c}}$ \\
Imipramine & $40.15 \pm 3.62^{\mathrm{b}}$ & $1.86 \pm 0.05^{\mathrm{d}}$ & $9.14 \pm 0.52^{\mathrm{b}}$ \\
Saline & $22.16 \pm 0.84^{\mathrm{b}}$ & $0.70 \pm 1.04^{\mathrm{e}}$ & $7.78 \pm 0.32^{\mathrm{d}}$ \\
\hline
\end{tabular}

Values are expressed as Mean \pm SD; $(n=10)$.

Values carrying different superscripts vertically are significantly $(\mathrm{p}<0.01)$ different.

Table 5: Concentrations of total protein, cholesterol and triglyceride in the liver of rabbits administered (i.p) sertraline, clozapine, amitriptyline, imipramine and saline after 28 days.

\begin{tabular}{lccc}
\hline $\begin{array}{l}\text { Drug } \\
\text { administration }\end{array}$ & \multicolumn{3}{c}{ Liver } \\
\cline { 2 - 4 } & Protein (g/l) & Cholesterol (mmol/l) & Triglyceride (mmol/l) \\
\hline Sertraline & $22.75 \pm 3.16^{\mathrm{a}}$ & $3.30 \pm 0.24^{\mathrm{a}}$ & $6.14 \pm 0.42^{\mathrm{a}}$ \\
Clozapine & $19.98 \pm 2.04^{\mathrm{a}}$ & $2.10 \pm 0.41 \mathrm{~b}$ & $7.28 \pm 0.66^{\mathrm{b}}$ \\
Amitriptyline & $22.84 \pm 1.16^{\mathrm{a}}$ & $0.55 \pm 0.04^{\mathrm{c}}$ & $8.14 \pm 0.78^{\mathrm{c}}$ \\
Imipramine & $23.16 \pm 2.95^{\mathrm{a}}$ & $0.68 \pm 0.05^{\mathrm{d}}$ & $8.68 \pm 0.60^{\mathrm{d}}$ \\
Saline & $15.53 \pm 2.48^{\mathrm{b}}$ & $0.86 \pm 0.16^{\mathrm{a}}$ & $5.02 \pm 0.49 \mathrm{e}$ \\
\hline
\end{tabular}

Values are expressed as Mean \pm SD); $\quad(n=10)$.

Values carrying different superscripts vertically are significantly $(\mathrm{p}<0.01)$ different.

The serum concentrations of total protein, cholesterol and triglyceride of rabbits administered (i.p) sertraline, clozapine, amitriptyline, imipramine and saline for 28 days are presented in Table 6. There was no significant $(\mathrm{p}<0.01)$ difference in serum protein levels of rabbits administered sertraline, clozapine, amitriptyline, imipramine and saline. Serum cholesterol level of rabbits administered saline was significantly $(\mathrm{p}<0.01)$ lower than in rabbits administered respective drugs. However, rabbits adminis- 
tered amitriptyline and imipramine had significantly higher serum cholesterol levels as compared with those administered sertraline, clozapine or saline. Serum triglyceride levels in the rabbits administered the respective drugs or saline were not significantly different $(\mathrm{p}<0.01)$.

Serum alkaline phosphatase (ALP), aspartate transaminase (AST) and alanine transaminase (ALT) activities of rabbits administered sertraline, clozapine, amitriptyline, imipramine or saline for 28 days are presented in Table 7. Serum ALP activities of rabbits administered amitriptyline and imipramine were significantly $(\mathrm{p}<0.01)$ higher compared with those administered sertraline, clozapine or saline. However, serum ALP activity of rabbits administered clozapine was significantly the lowest. Serum AST and ALT activities of rabbits administered saline were significantly $(p<0.01)$ lower than in those administered the respective drugs (Table 7).

Liver ALP, AST and ALT activities of rabbits administered sertraline, clozapine, amitriptyline, imipramine and saline for 28 days are shown in Table 8. The liver ALP activity of rabbits administered saline were significantly $(\mathrm{p}<0.01)$ lower than in rabbits administered the respective drugs.

\section{DISCUSSION}

Behavioural changes were reported in rabbits intraperitoneally administered sertraline, clozapine, amitriptyline and imipramine for 28 days. The rabbits were restless and hyperactive, indicating significant stimulation of spontaneous activity of the nerves. Some of the rabbits demonstrated varying degrees of hair loss, especially around

Table 6: Concentrations of protein, cholesterol and triglyceride in the serum of rabbits administered (i.p) sertraline, clozapine, amitriptyline, imipramine and saline after 28 days.

\begin{tabular}{lccc}
\hline $\begin{array}{l}\text { Drug } \\
\text { administration }\end{array}$ & \multicolumn{3}{c}{ Serum } \\
\cline { 2 - 4 } & Protein (g/l) & Cholesterol (mmol/l) & Triglyceride (mmol/l) \\
\hline Sertraline & $62.18 \pm 4.43^{\mathrm{a}}$ & $2.50 \pm 0.06^{\mathrm{a}}$ & $4.96 \pm 0.27^{\mathrm{a}}$ \\
Clozapine & $62.68 \pm 2.49^{\mathrm{a}}$ & $1.78 \pm 0.04^{\mathrm{b}}$ & $5.10 \pm 0.18^{\mathrm{a}}$ \\
Amitriptyline & $63.37 \pm 3.82^{\mathrm{a}}$ & $3.26 \pm 1.02^{\mathrm{c}}$ & $5.48 \pm 0.32^{\mathrm{b}}$ \\
Imipramine & $64.80 \pm 4.10^{\mathrm{a}}$ & $3.66 \pm 1.52^{\mathrm{c}}$ & $5.62 \pm 0.61^{\mathrm{b}}$ \\
Saline & $64.23 \pm 2.30^{\mathrm{a}}$ & $1.58 \pm 0.07^{\mathrm{b}}$ & $5.02 \pm 0.42^{\mathrm{a}}$ \\
\hline
\end{tabular}

Values are expressed as Mean $\pm S D ; \quad(n=10)$.

Values carrying different superscripts vertically are significantly $(\mathrm{p}<0.01)$ different.

Table 7: Serum alkaline phosphatase (ALP), aspartate transaminase (AST) and alanine transaminase (ALT) activities of rabbits administered (i.p) sertraline, clozapine, amitriptyline , imipramine and saline after 28 days.

\begin{tabular}{lccc}
\hline $\begin{array}{l}\text { Drug } \\
\text { administration }\end{array}$ & \multicolumn{3}{c}{ Enzyme Activity } \\
\cline { 2 - 4 } & ALP (IU/l) & AST (IU/l) & ALT (IU/I) \\
\hline Sertraline & $24.25 \pm 1.26^{\mathrm{a}}$ & $96.18 \pm 4.47^{\mathrm{a}}$ & $14.50 \pm 1.62^{\mathrm{a}}$ \\
Clozapine & $10.74 \pm 1.03^{\mathrm{b}}$ & $85.26 \pm 2.93^{\mathrm{b}}$ & $13.47 \pm 1.52^{\mathrm{b}}$ \\
Amitriptyline & $30.67 \pm 2.53^{\mathrm{a}}$ & $79.84 \pm 3.53^{\mathrm{c}}$ & $14.25 \pm 1.36^{\mathrm{a}}$ \\
Imipramine & $46.84 \pm 3.18^{\mathrm{d}}$ & $79.57 \pm 4.69^{\mathrm{c}}$ & $12.43 \pm 1.85^{\mathrm{c}}$ \\
Saline & $26.27 \pm 2.43^{\mathrm{a}}$ & $64.75 \pm 5.48^{\mathrm{d}}$ & $9.62 \pm 1.70^{\mathrm{d}}$ \\
\hline
\end{tabular}

Values are expressed as Mean \pm SD ; $(n=10)$

Values carrying different superscripts vertically are significantly $(\mathrm{p}<0.01)$ different. 
Table 8: Liver alkaline phosphatase (ALP), aspartate transaminase (AST) and alanine transaminase (ALT) activities of rabbits administered (i.p) sertraline, clozapine, amitriptyline, imipramine and saline after 28 days.

\begin{tabular}{llcl}
\hline \multirow{2}{*}{$\begin{array}{l}\text { Drug } \\
\text { administration }\end{array}$} & \multicolumn{3}{c}{ Enzyme Activity } \\
\cline { 2 - 4 } & ALP (IU/l) & AST (IU/l) & ALT (IU/l) \\
\hline Sertraline & $83.94 \pm 3.61^{\mathrm{a}}$ & $96.18 \pm 5.93^{\mathrm{a}}$ & $84.25 \pm 7.60^{\mathrm{a}}$ \\
Clozapine & $75.97 \pm 3.32^{\mathrm{b}}$ & $87.15 \pm 3.65^{\mathrm{b}}$ & $80.75 \pm 2.23^{\mathrm{a}}$ \\
Amitriptyline & $92.8 \pm 4.43^{\mathrm{c}}$ & $92.84 \pm 4.25^{\mathrm{a}}$ & $88.43 \pm 3.26^{\mathrm{b}}$ \\
Imipramine & $87.12 \pm 6.80^{\mathrm{a}}$ & $89.57 \pm 4.59^{\mathrm{a}}$ & $90.14 \pm 4.87^{\mathrm{b}}$ \\
Saline & $66.43 \pm 2.40^{\mathrm{d}}$ & $77.50 \pm 3.12^{\mathrm{c}}$ & $71.75 \pm 3.28^{\mathrm{c}}$ \\
\hline
\end{tabular}

Values are expressed as Mean \pm SD; $\quad(n=10)$.

Values carrying different superscripts vertically are significantly $(\mathrm{p}<0.01)$ different.

the ear, neck and nose. Other behavioural signs observed in the rabbits, include dry nose and mouth, photosensitivity, frequent urination and disorientation. This observation is in agreement with previous reports of Karolewick et al. (1996), Camarini and Benedito (1997) and Ebuehi et al. (2004a, 2004b).

The intraperitoneal administration of amitriptyline and imipramine increased the body weights of rabbits. This suggests that these drugs may stimulate appetite, protein synthesis and ultimately body growth. Allison et al. (1999) initially reported a slight weight gain in human, while others reported sertraline caused weight loss (Cottingham, 2000). Wood et al. (2001) reported that chronic administration of potent and selective 5-HT antagonists does not induce weight gain in rat. The present findings concur with previous results that sertraline administration resulted in body weight loss of rabbit. It is not clear how amitriptyline and imipramine promoted growth. The mean liver and brain weights of rabbits administered imipramine were significantly higher than in rabbits administered sertraline, clozapine and amitryptyline. This may suggest that imipramine promotes organ growth, especially, liver and brain.

The increase in serum and brain serotonin levels of rabbit administered sertraline, clozapine, imipramine and amitryptyline drugs may promote serotonin synthesis in the brain. For example, the antidepressant effect of setraline is presumed to be linked to its ability to inhibit the uptake of serotonin (Frazer, 1997). Sertraline potently inhibits the uptake of serotonin into neurons in vitro. Sertraline lowers 5-hydroxy indole acetic acid level in the brain by reducing serotonin (5-HT) turn over (Goodman-Gilman et al., 2006). This probably accounts for the increase in concentration of serum and brain serotonin of rabbits administered sertraline. From the wealth of literature, there is no report on whether intraperitoneal administration of clozapine, imipramine and amitriptyline affects serum and brain serotonin levels. It could be suggested that these antidepressants may also intrasynaptically inactivate serotonin.

Additionally, data of the study obtained in the serum and brain serotonin could also suggest that the transport of these antidepressants or their metabolites across the blood brain barrier (BBB) was not impaired and did not reflect any blockage of serotonin receptors. Previous studies by Cottingham (2000), reported that thioridazine, an antipsychotic drug, blocks cholinergic, adreninergic and histamine receptors causing a variety of side effects. The significantly higher levels of serotonin in rabbits administered these respective antidepressants may also mediate neural functions culminating in the behavioural changes observed in rabbits used in this study.

Ebuehi et al. (1993; 1996; 1999; 2001 and 2006) previously reported that malnutrition, marijuana smoking, caffeine and ethanol consumption altered the metabolism of 5-HT in the rat. For instance, caffeine consumption enhanced 5HT levels in plasma 
and brain, while a decrease in 5-HT level was found in acute and chronic ethanol treated rats. It has been reported that imipramine increases plasma 5-HT level by blocking the re-uptake of 5-HT, more so than most secondary amine tricyclics (Camarini and Benedito, 1997).

The protein, cholesterol and triglyceride concentrations in serum, liver, and brain were significantly elevated in rabbits administered the respective antidepressants. These findings may indicate that these drugs potentiate protein and lipid biosynthesis. However, the precise mechanism of action by these drugs remain to be ascertained, viz a viz the roles they play in the biosynthesis of these biomolecules.

Too little is known about the influence of antidepressants on the synthesis of biomolecules. Ebuehi et al. (2004a) previously reported that sertraline and thioridazine administration potentiated protein levels in the brain, liver and heart of rabbits, but had no effect on brain monoamine oxidase activity. Some of the present findings in this study are in harmony with the data obtained by previous workers (Frazer, 1997; Cottingham, 2000; Ebuehi et al., 2004b), but data on the effects of these anti-depressants on cholesterol and triglyceride levels in serum, liver and brain, are relatively a new contribution to the existing body of knowledge.

Serum and liver alkaline phosphatase, aspartate transaminase (AST) and alanine transaminase (ALT) activities in rabbits administered sertraline, clozapine, amytriptyline and imipramine were elevated and since they are serum liver-derived enzymes, data from this study indicate that administration of these drugs may pose a threat to liver damage and disease (Patel and O'Gorman, 1975; Ebuehi and Asonye, 2007). It is important to mention that the severity of liver damage could be more pronounced by imipramine or amytriptyline administration, while the least effect was by clozapine. Serum and liver alkaline phosphatase activities of rabbits administered imipramine or amytriptyline were the highest compared to those administered clozapine or sertraline, which indicate the possibility of abnormal destruction of erythrocytes, leukocytes and other cells by imipramine and amytriptyline (Steffensen et al., 1997). However, it is imperative to state that the outcome of the present findings may not necessarily be in agreement with researches carried out on depressed patients, which have the capacity to respond in a totally different way from healthy individuals.

In conclusion, data from the present study indicate that intraperitoneal administration of imipramine or amitriptyline produced a more pronounced effect than sertraline or clozapine on brain serotonin, activities of liver derived enzymes and blood chemistry of rabbits.

\section{ACKNOWLEDGEMENTS}

The research work was supported by the University of Lagos Central Research Grant (CRC 99/2000/2001). The authors are grateful to Mr. O. OJO of the Laboratory Animal Centre of the College of Medicine of the University of Lagos, Lagos, Nigeria , for his technical assistance in the handling of the animals.

\section{REFERENCES}

Allison DB, Mentore JL, Heo M, Chandler LP, Cappelleri JC, Infante MC, Weiden PJ. 1999. Antipsychotic-induced weight gain: a comprehensive research synthesis. Am. J. Psychiatry., 156: 1686-1696.

Banki CM. 1978. Alterations of CSF, 5HIAA and total blood 5HT content during

clozapine treatment. Psychopharmacology, 56: 195-198.

Boyer EW, Shannon M. 2005. The serotonin syndrome, Review. New Engl. J. Med., 352(23): 2454-2456.

Bustillo JR, Buchanam RW, Irish D, Breier A . 1996. Differential effect of clozapine on weight: a controlled study. Am. J. Psychiatry, 153: 817-819.

Camarini R, Benedito MAC. 1997. Chronic imipramine treatment-induced changes in acetylcholinesterase (EC 3.1.1.7) activity in discrete rat brain regions. Braz. J. Med. Biol. Res., 30(8): 955-960.

Cantrell R, Gillespie W, Altshuter L. 1999. Fluoxetine and sertraline dosages in major depression. Depr. Anxiety., 9: 7882.

Cohen BM, Lipinki JE, Waternaux D. 1989. A fixed dose study of the plasma concentration and clinical effects of 
thioridazine and its major metabolites Psychopharmacology, 97: 481-488.

Cottingham J. 2000. Thioridazine/Mellaril Parkinson's List Drug Data-base index; $1-4$.

Doorgan DP, Caillard V. 1988 . Sertaline: a new antidepressant. J. Clin. Psychiatry., 49: 46-47.

Dursun SM, Szemis A, Andrews H, Whitaker P, Revelev MA. 2000. Effect of clozapine and typical anti-psychotic drug on plasma 5HT turnover and impulsivity in patients with schizophrenia: a cross-sectional study. $J$. Psychiatry Neurosci., 25(4): 347-352.

Ebuehi OAT, Akinwande AI. 1993 . An indirect evaluation of the effect of material and post weaning protein and tryptophan malnutrition on the central serotoninergic metabolism. Nig. Qt. J. Hosp. Med., 5(1): 48-55.

Ebuehi OAT, Adenuga AO, Erinle OO. 1999. Effect of caffeine and ethanol consumption on the metabolism of 5hydroxy tryptamine in rats. J. Med. and Med. Sci., 1(1): 31-38.

Ebuehi OAT, Akinwande AI. 1996. Maternal and post weaning protein and tryptophan malnutrition on serotonin concentration in rat platelets. West Afr. J. Biol. Sci., 4(2): 122-124.

Ebuehi OAT, Akinwande AI, Famuyiwa OO, Uzodinma EO. 2005. Effect of marijuana smoking on blood chemistry and serum biogenic amines concentrations in Humans. Nig. J. Health and Biomed. Sci., 4(1): 20-24.

Ebuehi OAT, Sanya AO, Lewis OA, 2004. Sertraline and Thioridazine on the metabolism of serotonin in Rabbit Brain, Liver and Heart. African Scientist, 5(1): 27-33.

Ebuehi OAT, Asuni OQ, Kayode YC, 2004. Effect of sertraline and haloperidol on the metabolism of adrenaline and histamine in rabbit brain. African Scientist, 5(1): 21-26.

Ebuehi OAT, Bishop SA, Famuyiwa OO, Akinwande AI, Ladengan, OA, 2001. Biogenic amines metabolism and blood chemistry of psychiatric patients. Afr. Med. and Medical Sci., 30: 269-273.

Ebuehi OAT, Asonye CL, 2007. Gender and Alcohol consumption affect human serum enzymes protein and bilirubin. Asian J. Biochemistry 2(5): 330-336.

Fernstrom JD, Hirsch MJ, 1977. Brain serotonin synthesis. Reduction in coramalnourished rats. J. Neurochem., 28: 877-883.

Feighner JP, 1999. Mechanism of action of antidepressant medications. J. Clin. Psychiatry, 60(4): 4-11.

Frazer A, 1997. Pharmacology of antidepressants. J. Clin. Psychopharmacology, 17: 125-127.

Goodman-Gillman A,Rall TW , Niel AS , Taylor P. 2006. The Pharmacological Basis of Therapeutics ( $11^{\text {th }}$ edn), Brunton et al. (eds.). McGraw-Hill Medical Publishing Div.: New York, USA; 512634.

Karolewick B, Antiewiez-Micchaluk L, Micha J, Vetulani JH, 1996. Different effects of chronic administration of haloperidol and primozide on dopamine metabolism in the rat brain. Eur. $J$. Pharmacol., 313(3): 181-186.

Kane J, Honigfied G, Singer J. 1989. Clozapine for treatment-resistant schizophrenic; result of a U.S. multicentre trial. Psychopharmacology, 99: 560-563.

Klerman GL, Cole JOC, 1976. Clinical pharmacology of imipramine and related antidepressant compounds. Int. J. Psychiatry, 3: 267-304.

Marken PA, 2000. Selecting a selective serotonin reuptake inhibitor: Clinically important distinguishing features. Primary care companion. J. Clin. Psychiatry, 2: 205-210.

McConaghy N, Joffe AD, Kingston WR, et al., 1968. Correlation of clinical features of depressed outpatients with response to amitriptyline and protriptyline. $\mathrm{Br} . \mathrm{J}$. Psychiatry, 114: 103-106.

Lieberman JA, Safferman AZ, Pollack S. 1994. Clinical effects of clozapine in chronic schizophrenia: response to treatment and predictors of outcomes. Am J. Psychiatry, 151: 1744-1752.

Lowry OH, Rosenbrough NJ, Farr AL, Randall RL. 1951. Protein measurement with Folin phenol reagent. J. Biol. Chem., 193: 265-275.

Parrott AC, 2002. Recreational Ecstasy/ MDMA, the serotonin syndrome, and 
serotonergic neurotoxicity. Pharmacol Biochem Behav., 71: 837-844.

Patel S, O’Gorman P, 1975. Serum enzyme levels in alcoholism and drug dependency. J. Clin. Pathol., 28: 414417.

Ruch W, Asper HR, 1976. Effect of clozapine on the metabolism of serotonin in rat brain. Psychopharmacology, 46(1): 103109.

Solai LK, Mulsant BH, Pollock BG, et al., 1997. The effect of setraline on the pharmacokinetics of desipramine and imipramine. Clin. Pharmacol. Ther., 62: 145-156.

Steffensen FM, Sorensen HT, Brock A, Vilstrup H, Lauritzen T, 1997. Alcohol consumption and serum liver derived enzymes in a Danish population aged 3050 years. Int. J. Epidemiol., 26: 92-99.
Trujillo M. 1996. Antidepressants and the Brain. California State Univ. Press, USA; 24-36.

Wood MD, Reavill C, Trail B, Wilson A, Stean T, Kenneth GA, Liughtowler S, Blackburn TP, Thomas D, Gager TL, Riley G, Hollad V, Bromidge SM, Forbes IT, Middle DW. 2001. SB243213: A selective 2-HT2C receptor inverse agonist with improved anxiolytic profile: lack of tolerance and withdrawal anxiety. Neuro Pharmacology, 41: 186199.

Zimmerman M. 1983. Ethical guidelines for investigation of experimental pain in conscious animal. Pain., 16(2): 109-110. 